\title{
EVALUATION OF COLD TOLERANT HIGH YIELDING OIL PALM GERMPLASM IN GUANGDONG PROVINCE OF SOUTH CHINA, A NORTHERN TROPICAL REGION
}

\author{
ZENG XIANHAI*; PAN DENGLANG**; LIU ZHAO‡; CHEN JUNMING* and LIN WEIFU‡
}

\begin{abstract}
An evaluation of the vegetative growth, yield components and cold resistance traits from 38 pre-selected individual oil palm plants grown in six regions (populations) at the latitude (LAT) range between $20^{\circ} \mathrm{N}$ and $23^{\circ} \mathrm{N}$ in Guangdong Province, China was carried out during the period from April 2010 to April 2015. Analysis of variance showed significant differences in traits between the individual palms or the populations [except sex-ratio of female inflorescence and fruit bunch to female inflorescence, male inflorescence and fruit bunch (\%)(SR)]. Phenotypic correlation analysis showed that bunch number (NB) was positively correlated with fresh fruit bunch (FFB), but not significantly with average bunch weight (ABW). For the individual palms, it was found that the higher the LAT the lower the frond production (FP) and $L T_{50}$ and the higher fruit compaction rate (FCR), and the higher the $L T_{50}$ the lower the $A B W$. For the populations, the higher the $L A T$ the higher the $A B W$ and the lower the abortion ratio of female inflorescence to female inflorescence and fruit bunch (\%) (RAFM). Path coefficient analysis further revealed that for the individual palms $A B W$ was the major determinant in both $F F B$ and $N B$, and mainly determined by normal fruit higher per bunch $(\mathrm{kg})(A N F W)$ and percent of $A N F W$ to $A B W(\%)(F / B)$. For the populations, the major determining factors were ratio of aborted fruit bunch to fruit bunch (\%) (ABR) for FFB and NB, and inflorescence (male, female, bisexual and non-anthesis) and fruit bunch numbers per year (No.) NIB and $L_{50}$ for ABW. MM5 palm and Huazhou population were selected based on the major determining factors as high-yielding cold tolerant palm and population, respectively, which was consistent with the results of analysis of variance.
\end{abstract}

Keywords: oil palm, vegetative growth, yield, cold resistance, northern tropical regions.

Date received: 15 October 2015; Sent for revision: 4 January 2016; Received in final form: 27 May 2016; Accepted: 7 June 2016.

\section{INTRODUCTION}

Oil palm (Elaeis guineensis Jacq.), a typical tropical woody oil crop, generally grows at the latitudinal

* College of Agriculture, Hainan University, Haikou, Hainan 570228, People's Republic of China. E-mail: zxh200888@126.com

** Rubber Research Institute, Chinese Academy of Tropical Agricultural Sciences, Danzhou, Hainan 571737, People's Republic of China.

₹ Danzhou Investigation and Experiment Station of Tropical Crops of Ministry of Agriculture, Danzhou, Hainan 571737 , People's Republic of China. rangefrom $12^{\circ} \mathrm{S}$ to $15^{\circ} \mathrm{N}$ withmean monthly minimum temperatures of more than $19^{\circ} \mathrm{C}$ (Olivin, 1986), and gives the highest oil yield with average yield of $3.5 \mathrm{t}$ $\mathrm{ha}^{-1} \mathrm{yr}^{-1}$ and the full yield potential estimated at 11$18 \mathrm{t} \mathrm{ha}^{-1} \mathrm{yr}^{-1}$ under favourable conditions (Barcelos et al., 2015). The oil palm was introduced into China in 1926 , and mainly distributed at between $18^{\circ} \mathrm{N}$ and $25^{\circ} \mathrm{N}$, the northern tropical regions with occasional damages by typhoon, cold and drought (Zeng et al., 2015; Cao et al., 2009). Zeng et al. (2015) reported that a large number of oil palm were scattered planted as a landscape tree species in Guangdong, Yunnan, Hainan in China. These palms had undergone long- 
term natural domestication in the local conditions and might have important beneficial variations for utilisation.

The main yield components of oil palm are the number and the weight of harvested bunches and determined by sex ratio, bunch failure and mesocarp to total bunch dry mass ratio (Corley and Tinker, 2003). Earlier studies showed the relationships among traits in oil palm such as vegetative growth, yield and its components were proved to be related (Corley and Tinker, 2003). Analysis of variance (ANOVA) phenotypic correlations and path coefficient analysis could be used to determine the nature of relationships among the traits and help the breeder to reduce the number of traits to the minimum in breeding programmes (Rafii et al., 2013; Oboh and Fakorede, 1990; Corley et al., 1977). Significant negative phenotypic and genotypic correlations have been found to occur between the number of bunches and average bunch weight (ABW), while both two were positively correlated with fresh fruit bunch (FFB) (Corley et al., 1977; Obisesan and Fatunla, 1983). Oboh and Fakorede (1990) concluded that percentage of fruit per bunch was the most important determinant for FFB yield and number of bunches. Moreover, the number of leaves per palm, sex ratio (SR), percentage fruit per bunch and percentage mesocarp per fruit would be effective as indirect criteria for yield. Malaysia has drawn the minimum standards for the selection of high yielding tenera and dura materials, which are $\geq 170 \mathrm{~kg} \mathrm{yr}^{-1}$ and $\geq 150 \mathrm{~kg} \mathrm{yr}^{-1}$ per palm, respectively, with at least four consecutive years of recording, but the selection standards for each trait of interest may vary in different countries (Kushairi et al., 2011).

Studies on cold resistance of oil palm were rarely reported and mostly focused on field investigation of cold damage, microstructure observation and determination of physiological and biochemical indexes (Tarmizi and Marziah, 2000; Lei et al., 2014; Ruan et al., 2008; Ruan, 2008; Cao et al., 2009). However, the cold tolerant oil palm hybrid with $\mathrm{D} \times \mathrm{P}$ progenies (Bamenda $\times$ AVROS and Tanzania $\times$ AVROS) derived from the higher altitudes, bred in Costa Rica, have been successfully adapted to the higher altitudes up to $1500 \mathrm{~m}$ and latitudes (LAT) up to $25^{\circ} \mathrm{N}$ in Africa and South-east Asia. This indicates the possibility of selection of cold tolerant high yielding oil palm, although there seems to be little demonstrable progress (Chapman et al., 2001; Corley and Tinker, 2003).

The objectives of this experiment are to identify high yielding cold tolerant individual palms or populations by evaluating the vegetative growth, yield and cold resistance traits of pre-selected individual palms and populations and to select the major indexes affecting FFB, bunch number (NB) and $\mathrm{ABW}$ by analysing the correlation of various traits. The results were expected to provide some useful references for conservation and development of oil palm germplasm resources at a north fringe of tropic in China.

\section{MATERIALS AND METHODS}

A total of 38 individual oil palm were selected based on higher mean $\mathrm{BN}$ in respective populations in February 2010 from six regions (populations) in Guangdong Province, China at between the LAT of $20^{\circ} \mathrm{N}$ and $23^{\circ} \mathrm{N}$ (Table 1). Each individual palm was tagged with a short region name plus a code, for example SZ1 which indicates the first plant observed in Shenzheng population.

Data collection on individual palm basis was initiated in April 2010, i.e. two months after selection, and then continued until April 2015 at a regular interval of three to six months, namely two to four times per year.

Data on vegetative growth and development including frond production (FP), total number of inflorescences (including male, female and bracts without anthesising inflorescences) and bunches (NIB), sex ratio (the percentage of total number of female inflorescences and fruit bunches in total number of female, male, inflorescences and bunches) (SR), female inflorescence abortion ratio (the percentage of the total number of aborted female inflorescences in total number of female inflorescences and bunches) (RAFM), bunch abortion ratio (the percentage of the total number of aborted bunches in total number of bunches) (ABR) were collected from April 2010 to April 2015.

Yield components, including yield FFB, NB, ABW, were also determined. NB was the total of all the FFB counts; ABW was recorded based on a total of three FFB per individual palm during the period; FFB was thus the product between NB and ABW.

Bunch and fruit quality components, which include average number of fruits (the total number of normal fruits and infertile fruits) per bunch (ANF), total number of normal fruits per bunch (ANNF), average single fruit weight (ASFW), fruit compact ratio (the percentage of the total number of normal fruits in total number of fruits) (FCR), average normal fruit weight (ANFW), fruit to bunch ratio (the percentage of the average normal fruit weight in average fruit bunch weight) (F/B), shell to mesocarp thickness ratio $(\mathrm{S} / \mathrm{M})$, shell to kernel thickness ratio $(\mathrm{S} / \mathrm{K})$, mesocarp to kernel ration $(\mathrm{M} / \mathrm{K})$, were determined based on three FFB per individual palm with 10 normal fruits per bunch. Some measurements of bunch and fruit quality such as the selection methods for fruits and the determination of ASFW using the 'bunch analysis' technique developed at the Nigerian Institute for 
Oil Palm Research (NIFOR) (Henson and Dolmat, 2004) were used in this study.

Semi-lethal temperature $\left(\mathrm{LT}_{50}\right)$ was measured in April 2014 as cold tolerance reference index. The healthy, intact leaflets on both sides of middle leaf rachis of frond in middle canopy toward sunny sides were selected as test materials. After leaves in vitro were placed under low temperature stress at $7^{\circ} \mathrm{C}, 4^{\circ} \mathrm{C}, 1^{\circ} \mathrm{C},-2^{\circ} \mathrm{C},-5^{\circ} \mathrm{C}$ and $-8^{\circ} \mathrm{C}$ for $12 \mathrm{hr}$ with artificial low temperature constant temperature bath (equipment model BILON-W-803S), a EC215 conductivity meter was used to measure the conductivity of the solutions. The relative electrical conductivity was calculated with the following formula, i.e. (S1 - CK / S2 - CK) × 100\%, where S1 is the electrical conductivity value of samples at the first measurement, S2 is the conductivity after boiling and CK is the conductivity of deionised water. The relative electrical conductivity was carried out according to the method described by Premachandra et al. (1991) with little modification. Afterwards, a regression analysis was conducted based on relative electrical conductivity with Logistic equation as recommended by Mo (1983), where $x$ represents the relative electrical conductivity, $y$ the processing temperature, $k$ the relative conductivity saturation value, $a$ and $b$ the equation parameters.

One-way repeated randomised block design ANOVA and two-way non-repeated complete randomised block design ANOVA were used for data ANOVA, where the former ANOVA was carried out for all traits to compare the significant differences in individual palms and populations, while the latter ANOVA was performed to evaluate the effects of individual palms and years, populations and years on parameters of FP, NIB, NB, FFB, SR, RAFM and ABR. Statistical analyses were conducted using the statistical software package DPS 7.05 for Windows XP (Tang et al., 2007). Multiple comparison method of data was adopted with Duncan's New Multiple Range Method (SSR). All results of ANOVA presented are the mean values \pm standard errors obtained from at least three replications.

Phenotypic correlations among the traits including (LAT) were computed with the data of individual palms (38 palms) and populations (six populations) through replications. Of the replications, the observation data on FP, NIB, NB, FFB, SR, RAFM and ABR were determined by years, i.e. five replications in a set of data, while the data on ABW, ANF, ANNF, ASFM, ANFW, FCR, F/B, S/M, $S / K$ and $M / K$ were derived from three replications, with only three bunches per plant, and the number of samples per palm used for determining the $\mathrm{LT}_{50}$ was obtained in April 2014 with three leaf sample replications.

Path coefficient analysis, developed by Wright (1923), was used to determine the inter-relationships among all traits in a set of data, with FFB, NB or
$\mathrm{ABW}$ as the dependent variable and the other traits the independent variables. This method aids the partitioning and interpretation of cause-and-effect relationships among a set of variables. A direct casual effect $(p)$ of a trait on the dependent trait $(y)$ is indicated by a single one-directional path. Indirect causal effects are indicated by alternate paths from a trait, $i$, through another trait, $j$, to the dependent trait. Thus, a single indirect effect is equal to the product of path coefficient along a given path, i.e., indirect effect $=($ rij) $($ pjy), where rij $=$ correlation coefficient of trait $I$ with $j, i \neq j$; $\mathrm{p}_{\mathrm{jy}}=$ direct effect (or path coefficient) of trait $j$ on the end product, $y ; r_{i j} p_{j y}$ = indirect effect (product of path coefficient along a given path).

\section{RESULTS AND DISCUSSION}

\section{One-way ANOVA in Vegetative Growth, Yield and Cold Resistance Traits of Pre-selected Individual Palms and Populations}

ANOVA in all traits showed significant differences in the selected individual palms (Table $2)$, which indicated high variability. The MM7 in Maoming population had the highest FP (26.80 fronds $\left.\mathrm{yr}^{-1}\right)$ and high NIB (21.8 inflorescences and bunches $\left.\mathrm{yr}^{-1}\right)$, SR (74.25\%), NB (8.74 bunches $\left.\mathrm{yr}^{-1}\right)$ and FFB (61.9 $\left.\mathrm{kg} \mathrm{yr}^{-1}\right)$. The SZ12 in Shenzhen population had the highest FCR $(89.95 \%)$ and the maximum thickness of mesocarp with the lowest S/M (0.19) and the highest $M / K(0.88)$, while the lowest FP (12.6 fronds $\mathrm{yr}^{-1}$ ), NIB (9.00 inflorescences and bunches) and ANNF (166.00 fruits per bunch) were recorded with the lower NB (3.30 bunches $\left.\mathrm{yr}^{-1}\right), \mathrm{ABW}(7.02 \mathrm{~kg}$ per bunch) and FFB (23.18 kg $\left.\mathrm{yr}^{-1}\right)$. The SZ3 in Shenzhen population was recorded with the highest NB (15.33 bunches $\left.\mathrm{yr}^{-1}\right)$ attributed to the highest SR $(92.88 \%)$, while the lowest F/B $(11.67 \%)$ did not compensate for the ABW $(3.82 \mathrm{~kg}$ per bunch), resulting in lower FFB (58.59 $\mathrm{kg} \mathrm{yr}^{-1}$ ). The MM5 produced the highest FFB yield (115.40 kg $\mathrm{yr}^{-1}$ ) with the highest $\mathrm{ABW}$ (13.96 kg per bunch) and comparatively high NB (8.27 bunches $\left.\mathrm{yr}^{-1}\right)$. HZ6 had the highest F/B (54.26\%), which might be due to the highest ANF (1040.67 fruits per bunch), ANNF (611.33 fruits per bunch), ANFW (4.43 kg per bunch), $\mathrm{S} / \mathrm{M}$ (1.77) and the lowest $\mathrm{M} / \mathrm{K}(0.18)$. However, the highest ABR (54.24\%) resulted in low NB (6.40 bunches $\left.\mathrm{yr}^{-1}\right)$ and thus affected its FFB (42.60 $\left.\mathrm{kg} \mathrm{yr}^{-1}\right)$ yield. In addition, the highest values for NIB (23.60 inflorescences and bunches $\mathrm{yr}^{-1}$ ), ASFW (18.61 $\mathrm{g}$ per fruit) and RAFM (23.55\%) were recorded in MM3 in Maoming population, SZ4 and HZ4 in Shenzhen population, respectively. Previous studies showed that vegetative growth was closely related to bunch yield and both had a balance between the competing sources and sinks (Corley and Breure, 1992). To 


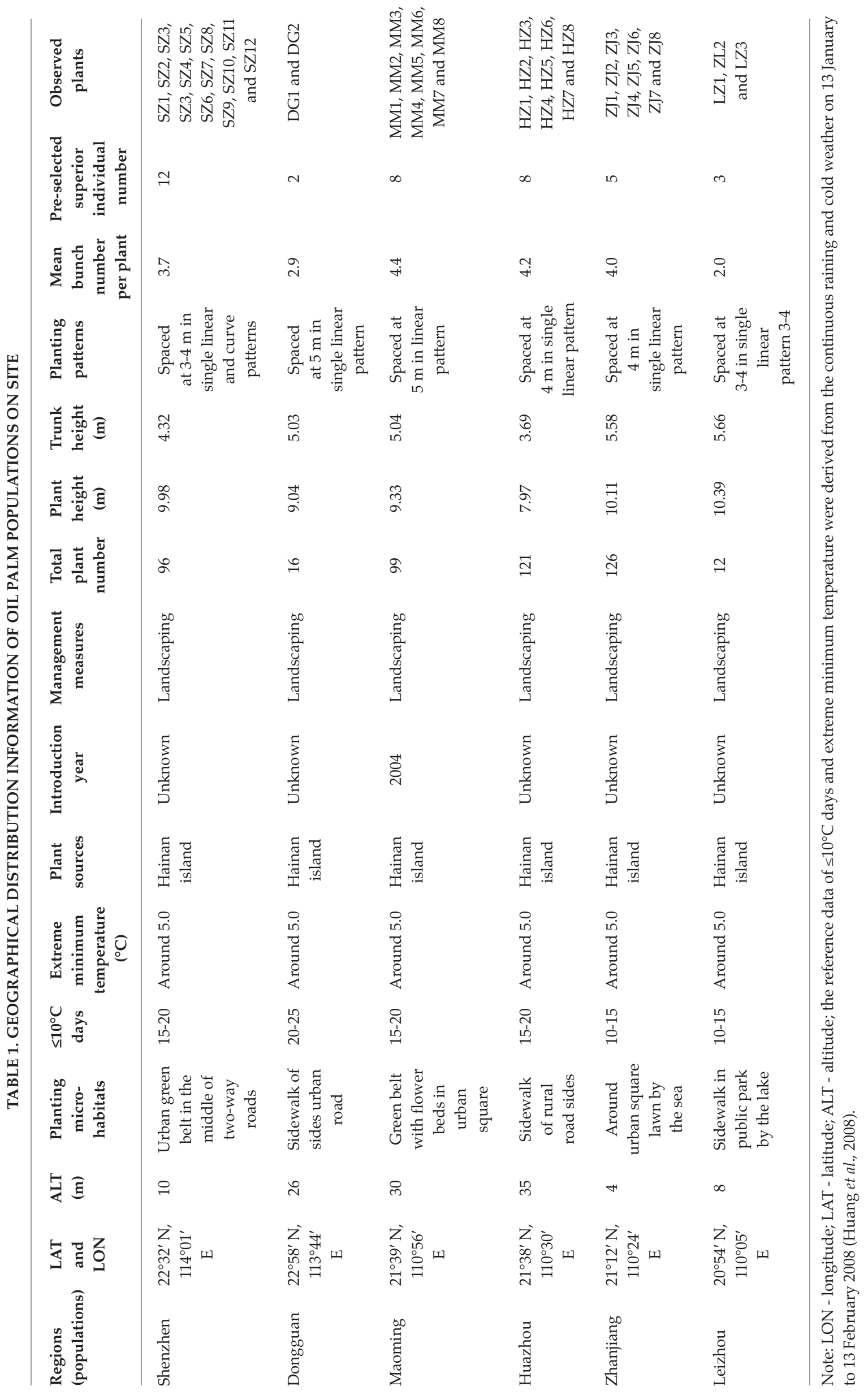


further understand the cold resistance of oil palm, $\mathrm{LT}_{50}$ was obtained as the reference index. Results showed that SZ7 and SZ1 in Shenzhen population had the highest cold resistance at the lowest $\mathrm{LT}_{50}$ $\left(-6.19^{\circ} \mathrm{C}\right)$ and the lowest cold resistance at the highest $\mathrm{LT}_{50}\left(-2.69^{\circ} \mathrm{C}\right)$. However, cold resistance to plants is a complex quantitative trait, which is influenced by different genetic characteristics, organ tissues, environment and cultural conditions.

ANOVA of vegetative growth, yield and cold resistance traits in different populations (Table 3) showed that the traits except FP (18.22-22.96 fronds $\left.\mathrm{yr}^{-1}\right)$, NIB (13.46-20.14 inflorescence and bunches $\left.\mathrm{yr}^{-1}\right)$, NB (4.06-9.02 bunches $\left.\mathrm{yr}^{-1}\right)$, ABR (19.09\%-33.82 $\%)$ and SR (59.80\%-81.10\%) in different populations were significantly different, which may be affected by environment and cultural operation factors, such as planting density, fertilisation and water, temperature, palm age, leaf pruning, inflorescence removal and genetic differences and so on (Corley and Tinker, 2003). The FFB yield in different populations was in the ranking order of Maoming (71.88 kg yr-1), Huazhou (61.36 kg yr-1), Shenzhen (50.62 kg yr-1), Zhanjiang (50.34 $\left.\mathrm{kg} \mathrm{yr}^{-1}\right)$, Dongguan (31.06 $\mathrm{kg} \mathrm{yr}^{-1}$ ) and Leizhou (10.34 $\mathrm{kg} \mathrm{yr}^{-1}$ ). Dongguan population had the highest ABW, followed by the populations in Maoming, Shenzhen, Huazhou, Zhanjiang and Leizhou, which yielded 8.33, 8.10, $7.17,7.13,6.07$ and $3.07 \mathrm{~kg}$ per bunch, respectively. The highest FFB in Maoming population was attributed to the lowest RAFM $(2.83 \%)$ and the higher S / M (1.08) and S / K (0.41), while in Leizhou population the FFB, ABW, ANF, ANNF, ASFW, ANFW and $\mathrm{LT}_{50}$ were the lowest and the ABR was the highest. FCR was significantly higher in Shenzhen population than in other populations. $\mathrm{ABW}$ and $\mathrm{LT}_{50}$ were significantly lower in Leizhou population.

\section{Two-way ANOVA in Some Vegetative Growth and Yield Traits in Different Years}

During the experimental period from April 2010 to April 2015, ANOVA for the traits of FB, NIB, NB, FFB, RAFM, ABR and SR was computed using the mean values of the data on individual palms (Table 4) and populations (Table 5). Results indicated that those traits were greatly influenced by years with an obvious inter-annual difference except SR based on populations, and both results showed similar variation trends among years. The FP, NIB, NB and FFB showed similar trends between years with an inverted ' $\mathrm{N}$ ' shape, while RAFM, ABR and SR were presented as inverted ' $\mathrm{V}$ ', ' $\mathrm{M}$ ' and ' $\mathrm{V}$ ' shapes, respectively.

The NIB (24.79 and 21.68 inflorescences and bunches), NB (19.31 and 15.77 bunches) and FFB (137.33 and $109.12 \mathrm{~kg}$ ) were observed highest in the first year 2010/2011, and FP and RAFM in the fourth year 2013/2014 with 25.45-25.89 fronds and 10.50\%$10.69 \%$, respectively. The highest ABR was recorded in the second year 2011/2012 (36.20\%) and the fourth year 2013/2014 (40.27\%) based on individual palms and populations, respectively. It was noted that the annual variations of SR were significantly affected by individual palms, and the highest value appeared in 2010/2011 (82.21\%), while there were no significant annual variations based on populations with the highest record in 2014/2015 (74.18\%). The SR, governing the potential NB and NIB which may be produced, was the major factor determining FFB yield (Turner and Gillbanks, 1974) and was verified in this study on account of each of NB, NIB, FFB and SR appearing highest in the same year 2010/2011. However, the effects on SR might have not only been due to the differences in genotype in individual palms alone but also to environmental factors or the interaction of both factors. Rates of FP were very similar in different environments, implying similar rates of inflorescence development. However, the annual FP and NIB observations showed significant inter-palm and inter-annual differences (Tables 2, 4 and 5), which were similar to the results reported in Malaysia (Corley, 1977).

\section{Phenotypic Correlation Analysis}

Phenotypic correlation analyses were carried out for all the traits in the selected superior individual palms (Table 6) and different populations (Table 7). The interpretation of the strength of a relationship is based on correlation of coefficient (r). Cohen (1988) estimated the $r \geq 0.70$ as very high relationship, $0.69<\mathrm{r}>0.50$ as high, $0.49<\mathrm{r}>0.30$ as moderate and $0.29<r \geq 0.10$ as low. Significant associations occurred in many cases, but only those involving $\mathrm{FFB}, \mathrm{NB}$ and $\mathrm{ABW}$ in relation to other traits will be discussed.

For individual palms, FFB was positively correlated with $\mathrm{ABW}\left(\mathrm{r}=0.71^{* *}\right)$, NB $\left(\mathrm{r}=0.65^{* *}\right)$, $\operatorname{NIB}\left(r=0.56^{* *}\right), \operatorname{ANFW}\left(r=0.56^{* *}\right), S / K\left(r=0.49^{* *}\right)$, $\operatorname{ANNF}\left(\mathrm{r}=0.44^{* *}\right)$, ANF $\left(\mathrm{r}=0.38^{*}\right)$ and $\mathrm{S} / \mathrm{M}(\mathrm{r}=$ $\left.0.37^{* *}\right)$, but negatively with $\mathrm{ABR}\left(\mathrm{r}=-0.47^{* *}\right)$. NB were positively correlated with $\mathrm{NIB}\left(\mathrm{r}=0.56^{* *}\right)$, SR $\left(r=0.45^{* *}\right)$ and $S / K\left(r=-0.35^{*}\right)$, and negatively with $\operatorname{ABR}\left(\mathrm{r}=-0.58^{* *}\right)$, but was not significantly correlated with ABW. ABW was positively correlated with each of ANFW $\left(r=0.67^{* *}\right)$, ANNF $\left(r=0.50^{* *}\right)$, $\operatorname{ANF}\left(r=0.44^{* *}\right)$ and FCR $\left(r=0.36^{*}\right)$, and negatively correlated with $\operatorname{LT}_{50}\left(\mathrm{r}=-0.34^{* *}\right)$.

Observations based on populations showed FFB and NB, which were positively correlated with each other $\left(\mathrm{r}=0.92^{*}\right)$, were positively correlated with NIB $\left(\mathrm{r}=0.95^{* *}\right.$ and $0.82^{*}$ respectively) and $\operatorname{ANF}\left(\mathrm{r}=0.86^{*}\right.$ and $0.82^{*}$ respectively), but negatively with $A B R$ $\left(\mathrm{r}=-0.95^{* *}\right.$ and $-0.92^{* *}$ respectively), while ABW showed positive associations with LAT $\left(r=0.84^{*}\right)$. In addition, FFB was positively correlated with $S / M$ 


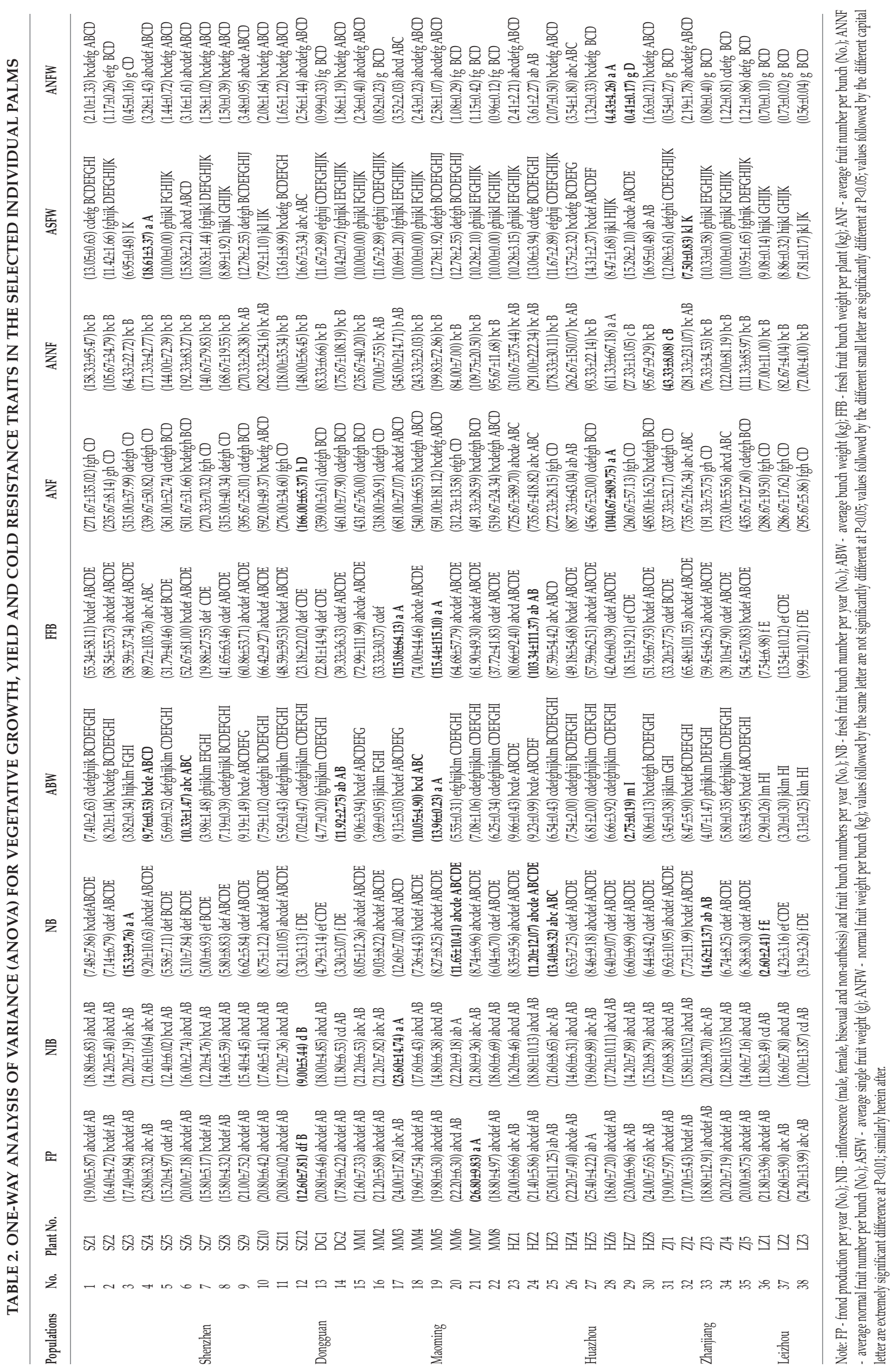




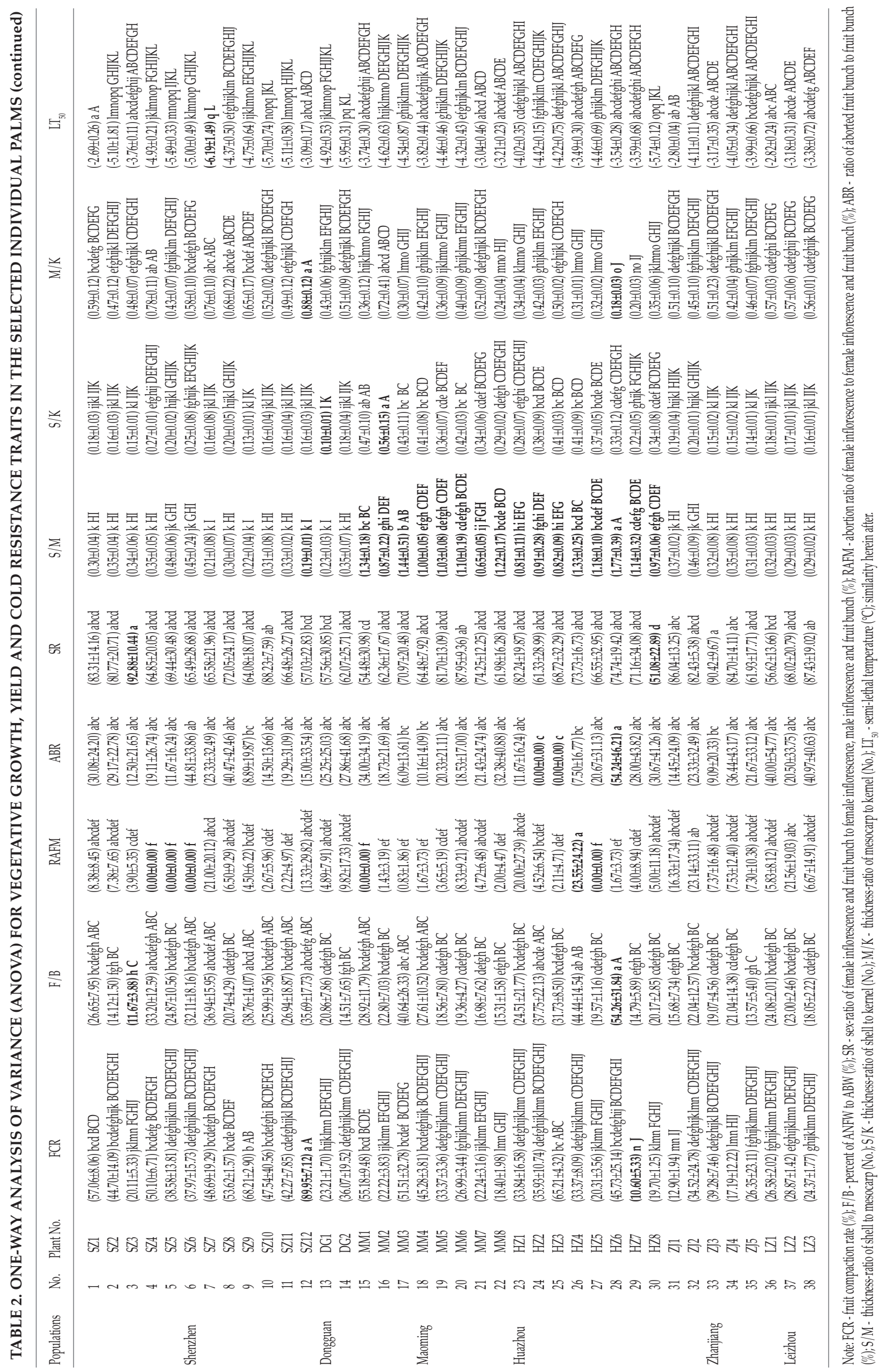




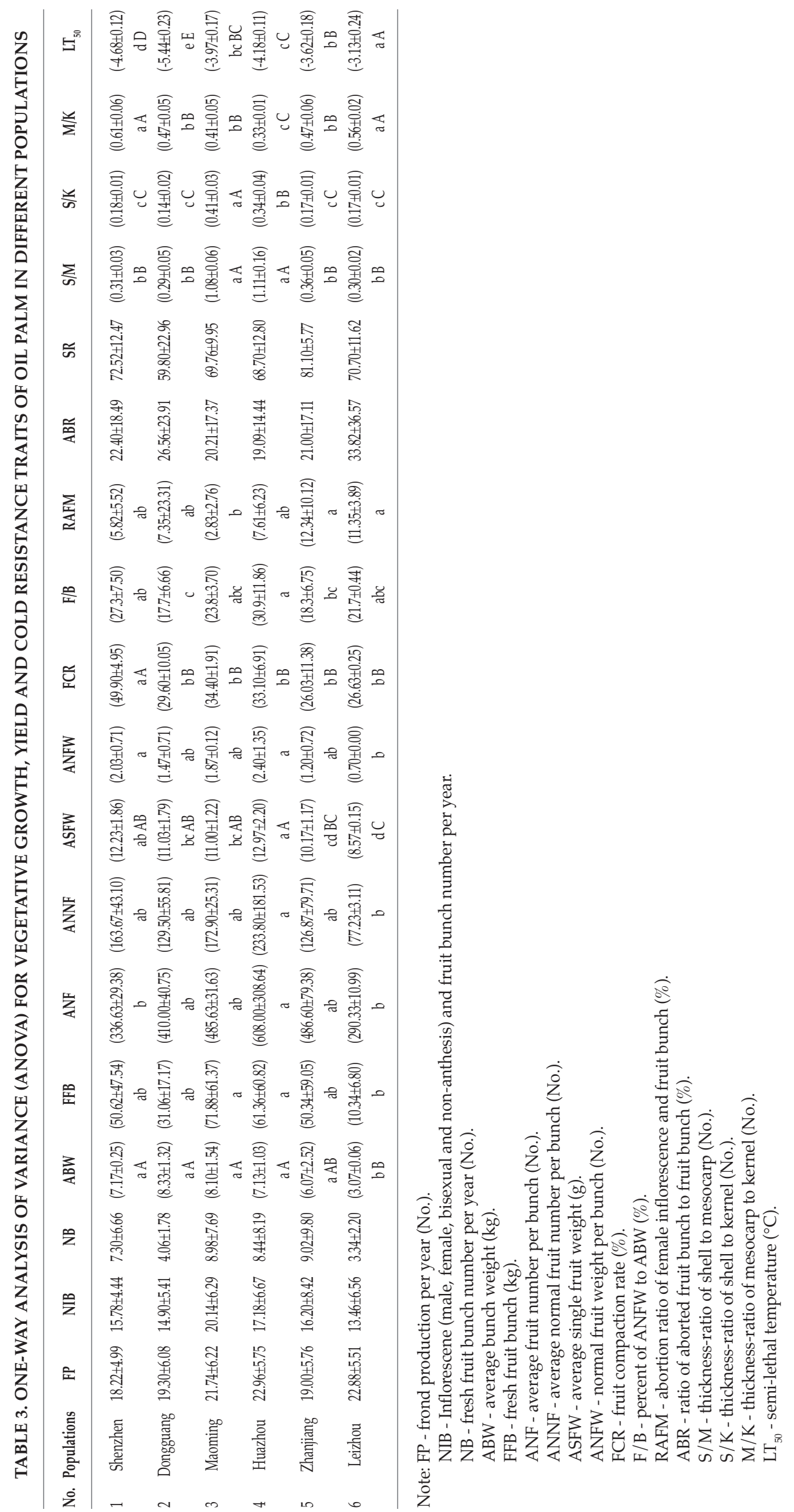



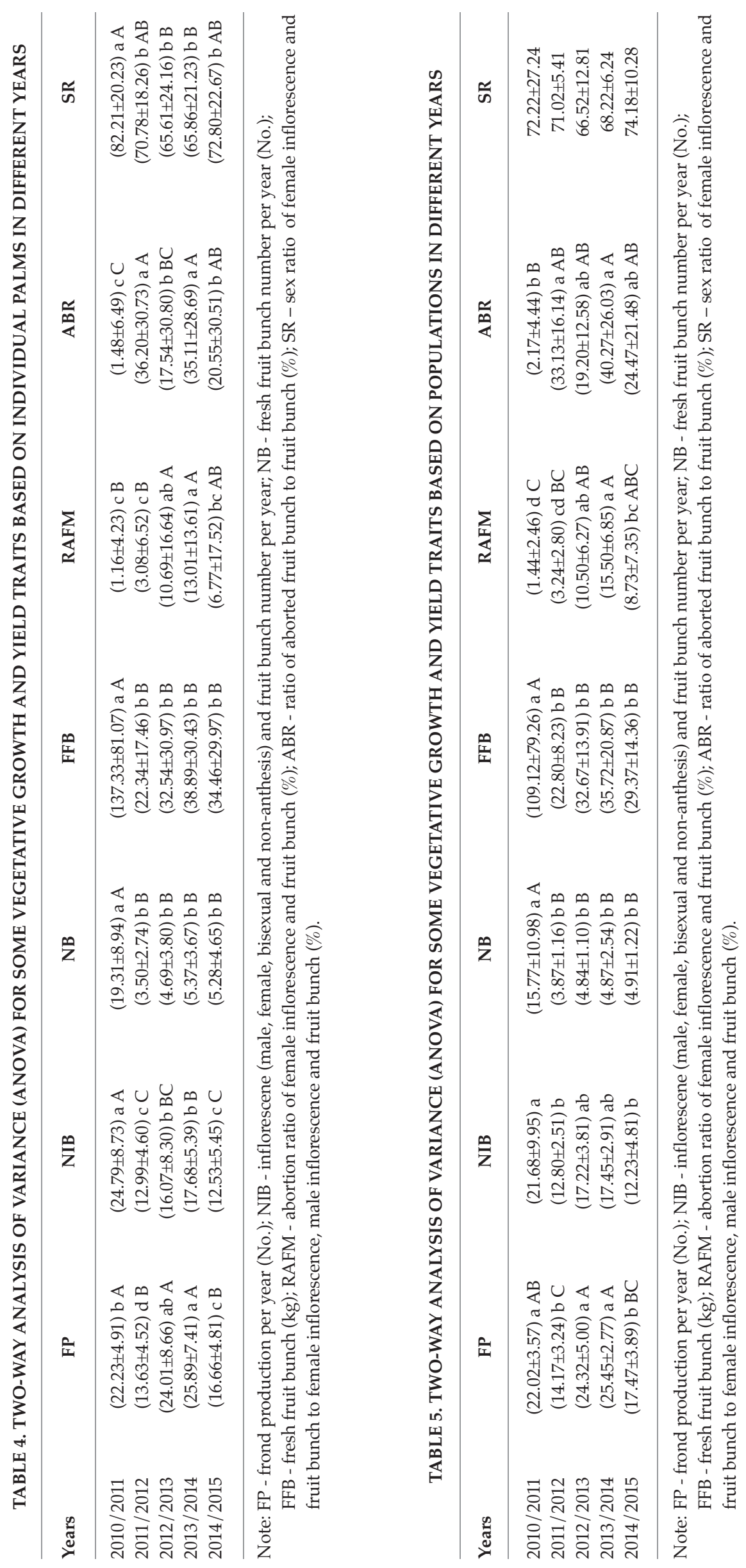
$\left(\mathrm{r}=0.83^{*}\right)$ and $\mathrm{S} / \mathrm{K}\left(\mathrm{r}=0.81^{*}\right)$, and negatively with $\mathrm{M} / \mathrm{K}\left(\mathrm{r}=-0.85^{*}\right)$.

Corley et al. (1971) suggested that significant, negative, phenotypic and genotypic correlations have been found to occur between NB and ABW, while $\mathrm{NB}$ and $\mathrm{ABW}$ were positively related to FFB. Oboh and Fakorede (1990) reported that NB was positively correlated with FFB and ABW. But our study showed that $A B W$ was not significantly correlated with NB, which indicated that these two traits might be important evaluation factors. Owing to the lack of obvious correlation between $\mathrm{ABW}$ and FFB yield in populations, the ABW, as one of major components of FFB yield, might not be feasible in the selection of high FFB yielding populations. ABW depends on FCR and ASFW, and appears to have seasonal fluctuations, but ABW changed much less than NB (Broekmans, 1957). Moreover, some of useful correlations with $\mathrm{ABW}$ had been found, i.e. $\mathrm{LT}_{50}$ and LAT.

Bunch failure (bunches fail to develop from anthesis, leading to absence of fruit set), is one of yield determining factors and may result from poor pollination, bunch rot, over bearing and heavy pruning, etc. (Corley and Tinker, 2003). The abovementioned results also revealed that the ABR played a key role in FFB and NB in northern tropical regions of China since the growth, flowering, fruiting and maturing of oil palm would greatly suffer from continuous drought and low temperature at times. Cao et al. (2009) investigated that drought for continuous nine months in Hainan Province (3.4-20.9 mm per month from September 2004 to April 2005) caused a $38 \%-57 \%$ decrease in frond production, and the development of inflorescence, sex ratio, pollen quality, fruiting and maturing were also subjected to drought damage. Furthermore, the continuous low temperature for 32 days (mean temperature $8^{\circ} \mathrm{C}-15^{\circ} \mathrm{C}$ with extreme minimum temperature $5^{\circ} \mathrm{C}-8^{\circ} \mathrm{C}$ from 15 January 2008 to 25 February 2008) gave rise to cold injury to nearly all of inflorescences and immature bunches, resulting in a $20 \%$ decrease in FFB yield in the current year.

\section{Path Coefficient Analysis from Stepwise Regression Analysis}

Path coefficient analysis was used to further investigate the cause-and-effect relationships among the individual palms and populations for the traits FFB, NB, ABW.

For individual palms (Table 8), ABW gave the highest direct effect $\left(\mathrm{p}_{3 \mathrm{y}}=0.710\right)$ on FFB, followed by NB ( $\left.p_{2 y}=0.613\right)$, and FFB had the highest positive direct effect $\left(\mathrm{p}_{7 \mathrm{y}}=0.763\right)$ on NB. ABW, although not significantly correlated with $\mathrm{NB}$, had the highest negative direct effect on $\mathrm{NB}\left(\mathrm{p}_{3 \mathrm{y}}=-0.544\right)$. Indirect effects of ABW via FFB $\left(r_{37} p_{7 y}=0.542\right)$ and FFB via $A B W\left(r_{73} p_{3 y}=-0.386\right)$ on $N B$ were high and moderate, respectively. Although FFB had the highest correlation $\left(r=0.71^{* *}\right)$ with ABW, ANFW $\left(\mathrm{p}_{2 \mathrm{y}}\right.$ $=1.164$ ) had the highest positive direct effect on ABW while F/B ( $\left.\mathrm{p}_{4 \mathrm{y}}=-0.997\right)$ had the highest negative direct effect. Likewise, the indirect effects of ANFW via $\mathrm{F} / \mathrm{B}\left(\mathrm{r}_{24} \mathrm{p}_{4 \mathrm{y}}=-0.839\right)$ and $\mathrm{F} / \mathrm{B}$ via ANFW $\left(\mathrm{r}_{42} \mathrm{p}_{2 \mathrm{y}}\right.$ $=0.979)$ on ABW were very high. Furthermore, FCR had negligible direct effect on ABW ( $\left.p_{3 y}=0.154\right)$, although these two traits were positively correlated $\left(r=0.36^{*}\right)$ with each other, but the indirect effects of FCR via ANFW $\left(\mathrm{r}_{32} \mathrm{p}_{2 \mathrm{y}}=0.667\right)$ and FCR via F / B $\left(\mathrm{r}_{34}\right.$ $\mathrm{p}_{4 \mathrm{y}}=-0.580$ ) on ABW were high. Wong and Hardon (1971) found that FCR had significant correlations with $A B W$, and that ABW showed a linear increase with FCR. Results from Table 7 showed that FCR had significant correlations with $\mathrm{ABW}\left(\mathrm{r}=0.36^{*}\right)$. The results indicated ANFW and F/B played more important roles than NB in the ABW of individual palms, which is different from the previous studies of Corley et al. (1971) who considered that ABW was highly determined by NB, the higher NB the lower $\mathrm{ABW}$. It was clear that $\mathrm{ABW}$ was the most important factor influencing the FFB of individual palm, and that ANFW and F/B may be the main contributors to ABW.

Among the traits in different populations (Table 9), for FFB, ABR exerted the highest negative direct effect $\left(\mathrm{p}_{4 \mathrm{y}}=-0.578\right)$ and the highest negative relationship $\left(\mathrm{r}=-0.95^{* *}\right)$; NIB had the second highest direct effect $\left(\mathrm{p}_{1 \mathrm{y}}=0.492\right)$ and the highest positive relationship $\left(\mathrm{r}=0.95^{* *}\right)$; indirect effects of $\mathrm{M} / \mathrm{K}$ via $\operatorname{ABR}\left(\mathrm{r}_{34} \mathrm{p}_{4 \mathrm{y}}=-0.502\right)$ was high, and NIB via ABR $\left(\mathrm{r}_{14}\right.$ $\left.\mathrm{p}_{4 \mathrm{y}}=0.467\right), \mathrm{M} / \mathrm{K}$ via NIB $\left(\mathrm{r}_{31} \mathrm{p}_{1 \mathrm{y}}=-0.345\right)$ and $\mathrm{ABR}$ via NIB $\left(r_{41}\right.$ p1y $\left.=-0.398\right)$ were moderate. For NB, ABR showed the highest negative relationship ( $\mathrm{r}=-$ $\left.0.92^{* *}\right)$ and the highest direct effect $\left(\mathrm{p}_{3 \mathrm{y}}=-1.267\right), \mathrm{LT}_{50}$ had the second highest direct effect but the strength was moderate $\left(\mathrm{p}_{4 \mathrm{y}}=0.331\right)$. ANF and ASFW had low direct effects on NB $\left(p_{1 y}=-0.204\right.$ and $p_{2 y}=-0.105$, respectively), and were not significantly correlated with NB. But the indirect effects of ANF via ABR, and ASFW via ABR on NB were very high $\left(r_{13} p_{3 y}\right.$ $=1.188$ and $r_{23} p_{3 y}=0.998$ respectively). The ANF and ASFW had very highly negative correlations ( $r$ $=-0.95^{* *}$ and $\mathrm{r}=-0.94^{* *}$, respectively) with ABR. Obviously, the NB, ANF and ASFW of oil palm populations were mainly determined by ABR. The $\mathrm{LT}_{50}$ and NIB had no significant correlations with $\mathrm{ABW}$, but had the highest negative direct effect $\left(\mathrm{p}_{4 \mathrm{y}}\right.$ $=-0.828)$ and highest positive direct effect ( $\mathrm{p} 1 \mathrm{y}=$ 0.804 ) on $\mathrm{ABW}$, respectively. The $\mathrm{S} / \mathrm{K}$ had a very low and negative direct effect $\left(\mathrm{p}_{2 \mathrm{y}}=-0.056\right)$ and the highest positive indirect effect via NIB $\left(\mathrm{r}_{21} \mathrm{p}_{1 \mathrm{y}}=0.713\right)$ on ABW. RAFM also had a highly negative indirect effect $\left(\mathrm{r}_{31} \mathrm{p}_{1 \mathrm{y}}=-0.617\right)$ on $\mathrm{ABW}$, although the direct effect $\left(\mathrm{p}_{3 \mathrm{y}}=0.208\right)$ was low. Unlike the individual palms, ABR in populations was the common and principal factor affecting FFB and NB, or in another word lower ABR may increase FFB through a higher 


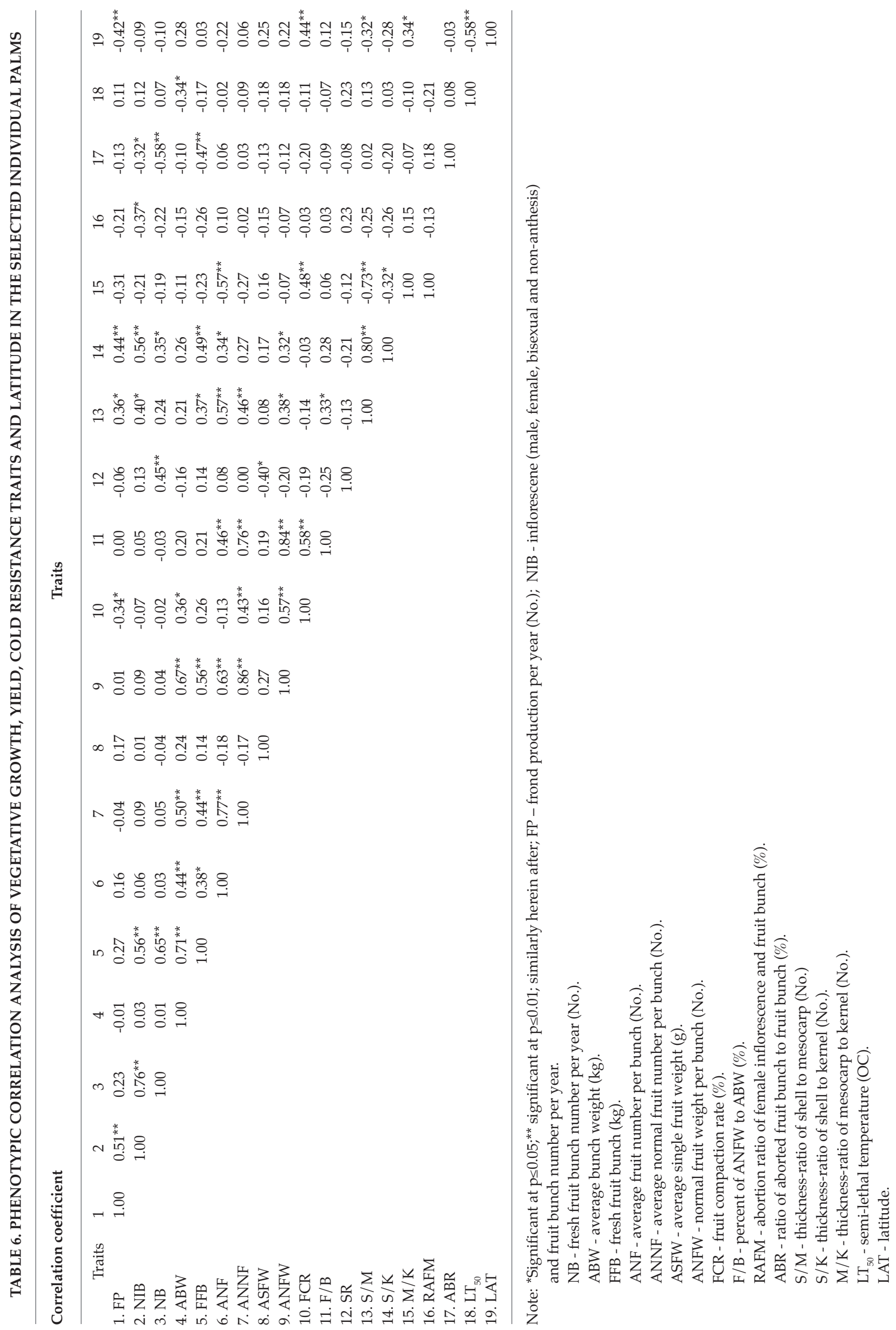




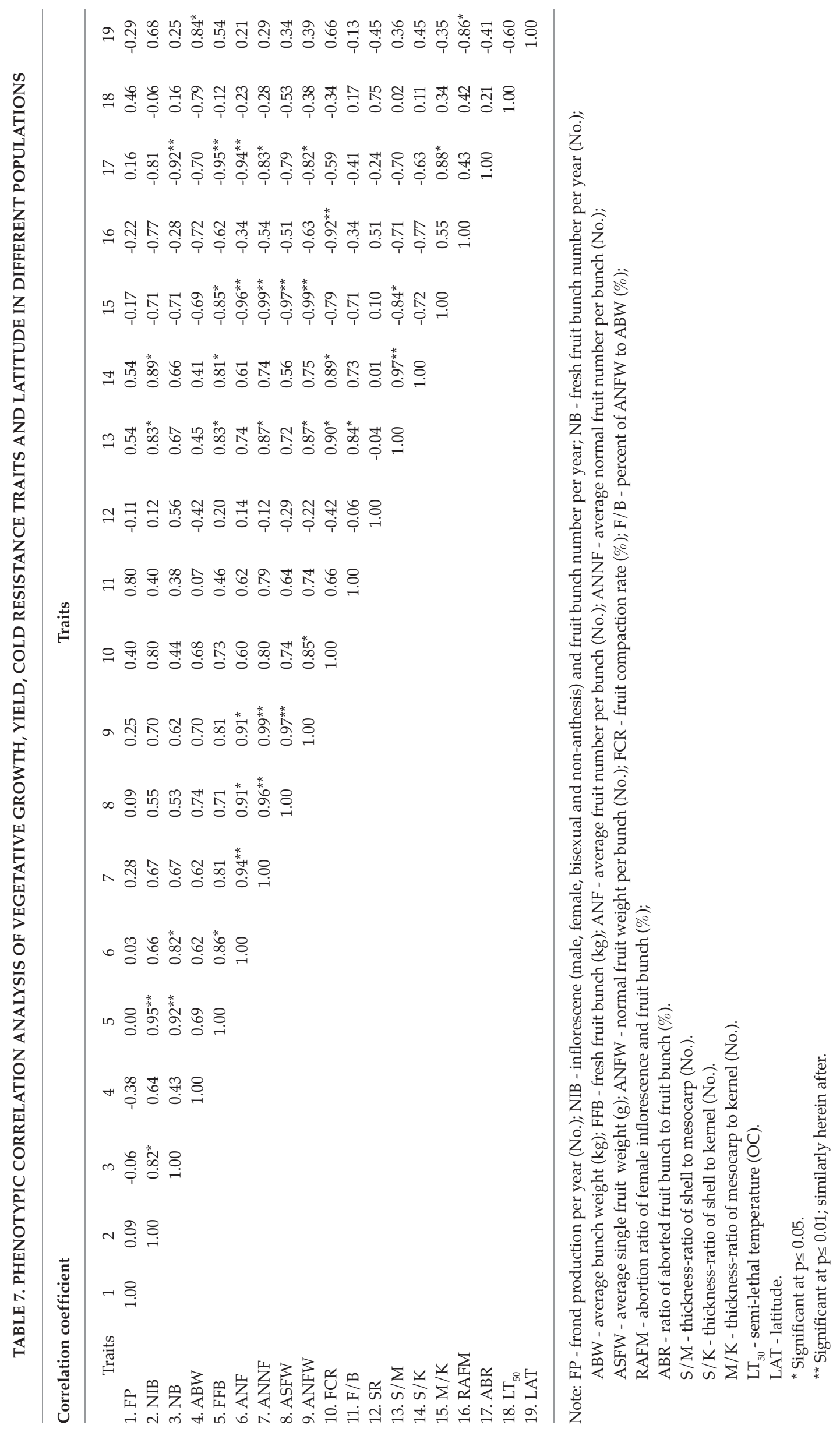



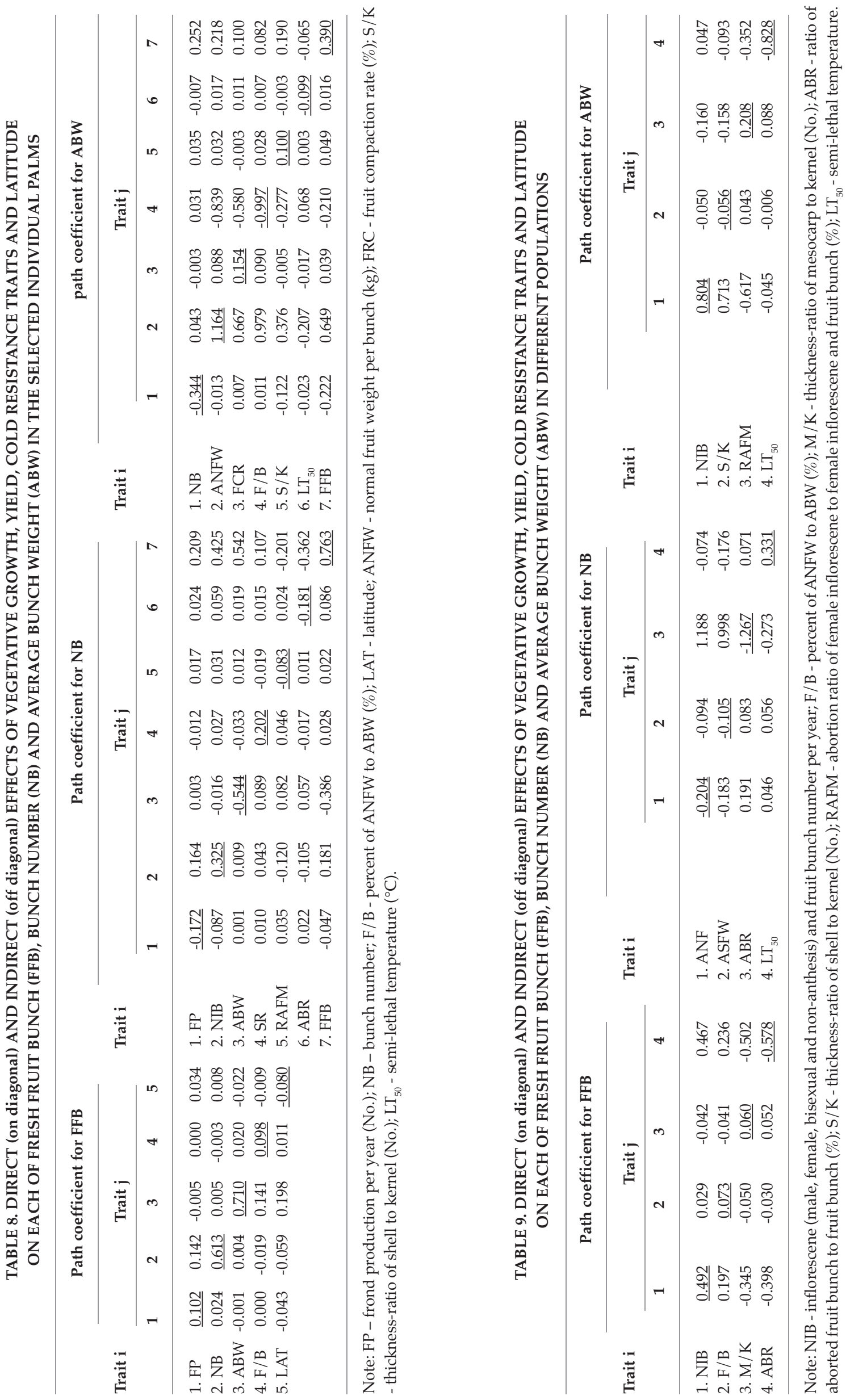
NB. However, as one of yield components, ABW was determined by $\mathrm{LT}_{50}$ and NIB, namely, the higher cold resistance and the higher NIB would lead to a higher ABW. These results are different from those reported by Oboh and Fakorede (1990) who thought that the number of male inflorescence and sex ratio were major determinants of ABW.

\section{CONCLUSION}

In this study, the variations in all traits appeared to have significant influence on individual palms. Some traits, such as FP, NIB, NB, ABR and SR had no apparent variations between populations, while other traits, such as FP, NIB, NB, FFB, RAFM and $\mathrm{ABR}$, showed strong inter-annual changes except SR based on populations data.

Phenotypic correlation analysis showed FFB was positively correlated with NIB, NB, ANF and negatively correlated with $\mathrm{ABR}$ in either individuals or populations. NB was positively correlated with FFB, NIB and S/K, and negatively with ABR. However, ABW had no significant correlation with other traits. For individual palms, the higher LAT was found to have lower FP and $\mathrm{LT}_{50}$ and higher FCR, and that the higher $\mathrm{LT}_{50}$ had the lower ABW. However, the results for populations showed that the higher LAT had the lower RAFM and the higher ABW.

Path coefficient analysis further revealed that for individual palms, $\mathrm{ABW}$ was the major determining factor in both FFB and NB with the highest positive and negative direct effect, respectively, but ABW was mainly directly determined by ANFW and F/B, not by FFB or NB. However, for the populations, ABR was the most important factor in the determination of FFB and NB, and $\mathrm{LT}_{50}$ and $\mathrm{NIB}$ were common determining factors with the highest negative and positive direct effect on $\mathrm{ABW}$, respectively. From this study, it seems that NIB, ANFW and FCR in individual palms and NIB, ABR, S/K, RAFW, M/K, ANF and ASFW in oil palm populations, would be effective as indirect evaluation criteria for $\mathrm{NB}, \mathrm{ABW}$ and FFB, but only NIB was likely to be selected as the common indirect factor in both individual palms and oil palm populations.

Based on the results of path coefficient analysis, MM5 with the highest $\mathrm{ABW}$ in individual palms and Huazhou population with the lowest ABR would hence, be selected as the highest FFB yield palm and population with a higher cold resistance, respectively, which was consistent with the results of one-way ANOVA.

\section{ACKNOWLEDGEMENT}

The authors greatly acknowledge the Fundamental Research Fund, from the Ministry of Agriculture (No.1630022014017) and Tropical Crops Resources
Protection Fund from the Ministry of Agricultural (No.15RZZY-53). We are also greatly indebted to Zhou Jiannan and Dr An Feng for their assistance in revising the manuscript.

\section{REFERENCES}

BARCELOS, E; RIOS, S DE A; CUNHA, R N; LOPES, R; MOTOIKE, S Y; BABIYCHUK, E; SKIRYCZ, A and KUSHNIR, S (2015). Oil palm natural diversity and the potential for yield improvement. Frontiers in Plant Science, 6(190): 1-16.

BROEKMANS, A E M (1957). Growth, flowering and yield of the oil palm in Nigeria. J. W. Afr. Inst. Oil Palm Res., 2: 187-220.

CAO, JIAN HUA; LI XIA OBO; LIN, WEI FU; XIE, GUI SHUI and CHENG, JUNMING, J M (2009). Survey on resistance of 12 species oil palm cultivated in the field. Chinese J. Tropical Agriculture, 29(2): 1-6 (in Chinese).

CHAPMAN, K R; ESCOBAR, $\mathrm{R}$ and GRIFFEE, $\mathrm{P}$ (2001). Cold tolerant (CT) or altitude adapted oil palm hybrid development initiatives in the Asia/ Pacific region. Proc. of the 2001 PIPOC International Palm Oil Congress - Agriculture Conference. p. 282288.

COHEN, J (1988). Statistical Power and Analysis for the Behavioral Sciences. Second edition. Lawrence Erlbaum Associates, Hillsdale, NJ.

CORLEY, R H V; HARDON, J J and TAN, GY (1971). Analysis of growth of the oil palm (Elaeis guineensis Jacq.). I. Estimation of growth parameters and application in breeding. Euphytica, 20: 307-315.

CORLEY, R H V (1977). Oil palm yield components and yield cycles. International Developments in Oil Palm. Incorporated Society of Planters. p. 116-129.

CORLEY, R H V and BREURE, C J (1992). Fruiting activity, growth and yield of oil palm. I. Effects of fruit removal. Expl Agric., 28: 99-109.

CORLEY, R H V and TINKER, P B (2003). The Oil Palm. Fourth edition. Backwell Science Ltd. p. 104180.

HENSON, I E and DOLMAT, M T (2004). Seasonal variation in yield and developmental processes in an oil palm density trial on a peat soil: 2 . Bunch weight components. J. Oil Palm Res. Vol. 16(2): 106-120.

HUANG, Z Z; DU, Y D; PAN, W J; ZHENG, J and ZENG, X (2008). Characteristics, influence and counter measures of a rare cold disaster 
in Guangdong Province in 2008. Guangdong Meteorology, 20(1): 8-11.

KUSHAIRI, A; MOHD DIN, A and RAJANAIDU, N (2011). Oil palm breeding and seed production. Further Advances in Oil Palm Research (2000 - 2010) (Wahid, M B; Choo, Y M and Chan, K W eds.). Volume 1. p. 79-80.

LEI, X T; XIAO, Y; XIA, W; MASON, A S; YANG, Y; MA, Z L and PENG, M (2014). RNA-seq analysis of oil palm under cold stress reveals a different C-repeat binding factor $(\mathrm{CBF})$ mediated gene expression pattern in Elaeis guineensis compared to other species. PLoS ONE, 9 (12): e114482. DOI: 10.1371 / journal.pine. 0114482 .

MO, HUIDONG H D (1983). Logistic equation and its application. J. Jiangsu Agricultural College, 4 (2): 53-57.

OBISESAN, I O and FATUNLA, T (1983). Genotype environment interaction for bunch yield and its components in the oil palm (Elaeis guineensis Jacq.). Theor Appl Genet, 64(2): 133-136.

OBOH, B O and FAKOREDE, M A B (1990). Interrelations among vegetative, yield and bunch quality traits in short-stem oil palm progenies. Euphytica, 46: 7-14.

OLIVIN, J (1986). Study for the siting of a commercial oil palm plantation. Oleagineux, 41: 113-118, 175-182.

PREMACHANDRA, G S; SANEOKA, $\mathrm{H}$ and OGATA, S (1991). Cell membrane stability and leaf water relations as affected by potassium nutrition of water-stressed maize. J. Experimental Botany, 42: 739-745.

RAFII, M Y; ISA, Z A; KUSHAIRI, A; SALEH, G B and LATIF, M A (2013). Variation in yield components and vegetative traits in Malaysian oil palm (Elaeis guineensis Jacq.) duraxpisifera hybrids under various planting densities. Industrial Crops and Products, 46: 147-157.

RUAN, Z P (2008). The Adapting Mechanism to Endure Cold of Three Introduced Palm Species. Xiamen University. p. 50-52.

RUAN, Z P; XIANG, P and LI, Z J (2008). Cold tolerance of Butia capitata, Acoelorrhaphe wrightii and Elaeis guineensis. J. Beijing Forestry University, 30(4): 77-81.

TANG, QI YI and FENG, M INGGUANG (2007). DPS (CData Processing System (Experimental Design, Statistical Analysis and Data Mining). Science Press, Beijing (in Chinese).

TARMIZI, A H and MARZIAH, M (2000). Studies towards understanding proline accumulation in oil palm (Elaeis guineensis Jacq.) polyemberyogenic cultures. J. Oil Palm Res. Vol. 6: 8-13.

TURNER, P D and GILLBANKS, R A (1974). Oil Palm Cultivation and Management. First edition. The Incorporated Society of Planter, Kuala Lumpur. p. 283-284.

WONG, Y K and HARDON, J J (1971). A Comparison of Different Methods of Assisted Pollination in the Oil Palm.

WRIGHT, S (1923). Correlation and causation. J. Agric. Res., 20: 557-585.

ZENG, X H; ZHANG, X C and ZOU, J X (2015). Studies analysis on the production utilization status and development potential of oil palm in northern tropical regions of China. China Agricultural Science. Science Press, Beijing (in Chinese). 